\title{
Morphology of submarine channels and paleo-flow discharge estimation: Itabapoana turbidity system, Campos Basin
}

Bruna Pandolpho ${ }^{\star}$, Gilmar Vital Bueno ${ }^{2}$, Arthur Antonio Machado ${ }^{3}$, Carlos E. Theodoro 4 , Antonio Fernando Harter Fetter Filho ${ }^{5}$, and Antonio Henrique da Fontoura Klein ${ }^{3}$, ${ }^{1}$ PPGOceano (UFSC), ${ }^{2}$ Universidade Federal Fluminense, ${ }^{3}$ Laboratório de Oceanografia Costeira (UFSC), ${ }^{4}$ PETROBRAS/CENPES, ${ }^{5}$ Laboratório de Dinâmica dos Oceanos (UFSC)

Copyright 2019, SBGf - Sociedade Brasileira de Geofísica

This paper was prepared for presentation during the $16^{\text {th }}$ International Congress of the Brazilian Geophysical Society held in Rio de Janeiro, Brazil, 19-22 August 2019.

Contents of this paper were reviewed by the Technical Committee of the $16^{\text {th }}$ International Congress of the Brazilian Geophysical Society and do not necessarily represent any position of the SBGf, its officers or members. Electronic reproduction or storage of any part of this paper for commercial purposes without the written consent of the Brazilian Geophysical Society is prohibited.

\section{Abstract}

This study aims to understand the Itabapoana turbidity system formation dynamics (erosion/deposition) development in the Campos Basin. To further propose a suitable paleocurrent model that characterizes the final geomorphology of the channels. It quantitatively describes the channels and valleys structural characteristics (width, depth, area, and length), through multichannel seismic data. The paleo-flow and discharge were calculated through the channel's morphometric parameters along with the modified Chezy equation which considers the continental slope environment specificities. Levee-channels, channel and distal lobes features were interpreted using OpendTect software together with the seismic attributes Cosine Phase and Amplitude RMS for each seismic profile. That highlights reflectors terminations and high amplitude impedance contrasts (i.e., turbidite sands). The average paleocurrent values of current velocity $(1.03 \mathrm{~m} / \mathrm{s})$ and flow discharge $\left(4.74 \times 10^{4}\right.$ $\mathrm{m}^{3} / \mathrm{s}$ ) combined with the seismic interpretation and geometry analysis demonstrated four distinct segments overlapped along the Itabapoana turbidity system. These different domains are indicated as (I) the channel's head partially filled with shallow features, (ii) active and deep channels features with aggrading paleo systems, (iii) the passage from a confined to an unconfined submarine system that leads to wider valleys features with wellmarked paleo-channels, and (iv) valleys with internal deposits.

\section{Introduction}

Canyons and submarine channels are well studied elongated negative relief features. They are relevant for their role as the main route for sediment transport into the deep-sea environment and potential hydrocarbon reservoirs. And for preserving the history of local climatic and oceanographic evolution (JANOCKO et al., 2013; POSAMENTIER; WALKER, 2006).

The morphological similarity between submarine channels and their terrestrial equivalent (i.e. rivers) raised the hypothesis that these deep-sea systems are the result of the interaction between fluvial systems and the continental shelf and slope (e. g. SHEPARD, 1972; RIZZO et al., 1994). However, the lack of explanation regarding canyons and submarine channels located below the lowest sea level changed the perspective of such systems. Consequently, the density-flow hypothesis became more relevant and many studies have demonstrated the importance of turbidity currents as a major control of the geometry and evolution of submarine canyon-channel systems (POSAMENTIER; KOLLA, 2003).

Turbidity currents are characterized as particle-laden gravity-driven underflows in which the particles are largely or wholly suspended by fluid turbulence (MEIBURG; KNELLER, 2009). Here, they are considered a result of continental slope sediment failures, responsible for eroding and forming submarine channels, that can be initiated by earthquakes or from the deposition on a slope leading to overstepping and failure. Therefore, studying the external geometry of submarine channels is a way to understand the paleo turbidity currents and their interaction with the sea-floor (MEIBURG; KNELLER, 2009).

In Brazil, many studies have analyzed the internal structures of paleochannels in the continental shelf in order to characterize the basin depositional system evolution (e. g. ABREU; CALLIARI, 2005; BRUSH et al., 2004; OSORIO, 2017; WESCHENFELDER et al., 2014). However, the external geometry of these systems do not receive the same attention. In general, only a few studies have used the geomorphological features of Quaternary systems in order to understand the paleo-processes that took place in submarine channels formation (e. g.; GIBLING, 2006; LI; GONG; STEEL, 2018; NORDFJORD et al., 2005; QIN et al., 2016).

Thus, a morphological and seismic stratigraphy analysis is performed through two-dimensional public Oil \& Gas industry seismic data of the Itabapoana turbidity channel system, (continental slope of Campos Basin, Brazil), to: (i) investigate the morphometric properties of the deepwater channels and their relationship with the structural and tectonic deep-sea environment; (ii) address the turbidity currents kinematic behavior and their influence in shaping the sea-floor; and (iii) propose the bankfull discharge capable of producing the final main channel morphology. This study aims to expand the research of canyon and channels systems in Brazil and improve the understanding of channel trajectories and architecture in divergent margin basis controlled by salt tectonics. 


\section{Geological Setting}

The Campos Basin (Figure 1) is in the territorial waters of the Rio de Janeiro and Espírito Santo states, occupying approximately $100,000 \mathrm{~km}^{2}$ in a passive margin tectonic context, whose submarine physiography is divided by the continental shelf, continental slope, São Paulo Plateau and continental rise or foot of slope (ALMEIDA; KOWSMANN, 2014).

The basin is stratigraphically divided into three major tectono-sedimentary units or mega-sequences: rift, transitional or initial drift, and passive margin or final drift sequence (CASTRO; PICOLINI, 2014; GUARDADO; GAMBOA; LUCCHESI, 1989). In the Carapeus Formation sandy sediments (mainly turbidites) were deposited during the final drift sequence by gravitational sediment fluxes (MIDDLETON; HAMPTON, 1976), responsible for developing submarine channels complexes (MORAES; BLASKOVSKI; PARAIZO, 2005) that can be confined in canyons or elongated troughs as tectonic and erosive features.

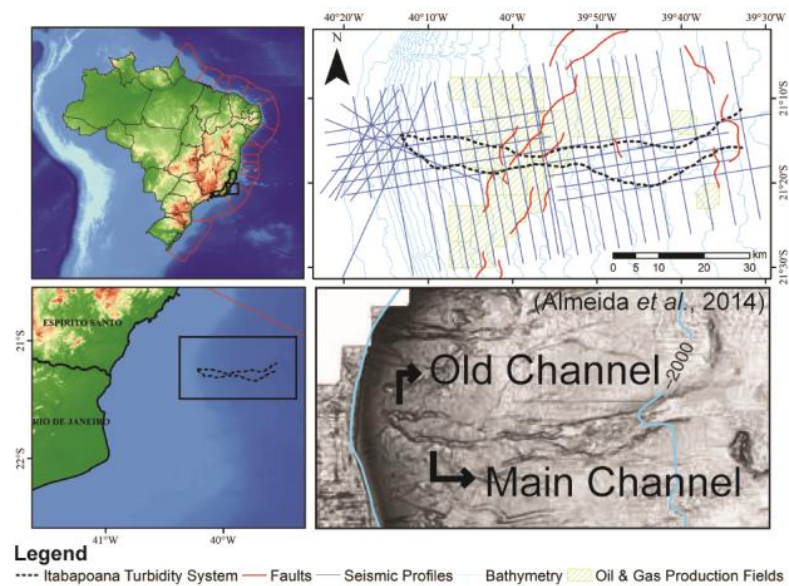

Figure 1 - Campos Basin localization and Itabapoana Turbidity System geomorphology and available data.

\section{Data and Methods}

\section{Seismic Data}

Sixty 2D public post-stack seismic data profiles spaced in $2 \mathrm{~km}$ profiles were provided by the National Agency of Petroleum, Natural Gas and Biofuels and used in this research. The main frequency between $10 \mathrm{~Hz}$ and $20 \mathrm{~Hz}$ provided an average vertical resolution of 25 meters. For time-depth conversions, a P-wave velocity of $1500 \mathrm{~m} / \mathrm{s}$ was used. The data polarity shows positive amplitudes reflections in black on the seismic profiles, representing an increase in acoustic impedance.

\section{Seismic Analysis}

Seismic profiles were enhanced through the application of seismic attributes using OpendTect software. Both RMS Amplitude (-4/4 time window analysis) and Cosine Phase attributes were used to identify high amplitudes (reflection strength), continuity and discontinuity of events, respectively.

The RMS Amplitude is calculated as the square root of amplitudes squares averages found in the time analysis window. Because amplitudes are squared before averaging, the RMS computation is very sensitive to extreme amplitude values. Consequently, it represents the reflection strength or high impedance contrast revealing bright spots and amplitude anomalies in the seismic data (CHOPRA; MARFURT, 2005; KOSON; CHENRAI; CHOOWONG, 2014). The Cosine Phase attribute is the cosine of the instantaneous phase of the seismic trace and is independent of amplitude, highlighting all the seismic reflectors and hence discontinuities and continuities (CHOPRA; MARFURT, 2005).

\section{Terminology and Morphometric Understanding}

Different channel hierarchical works have been proposed for the morphological studies in this subject (e. g. LINK et al., 1991; MCHARGUE et al., 2011). The two main terminologies used in this research are the channel and the valley morphological features.

Here, submarine channels or channel is the V- or Ushaped negative relief on the seafloor. While filled or subsurface channels are referenced as paleo-channels. Valley feature is the surface formed by the lateral and vertical migration of the channel or by a structurally related feature known as fault valleys (SHEPARD, 1981). Both channel and valley features were measured along the seismic profiles for width, height, cross-sectional area, aspect ratio (width/height), the thalweg depth (i.e. deepest point) and slope between the features.

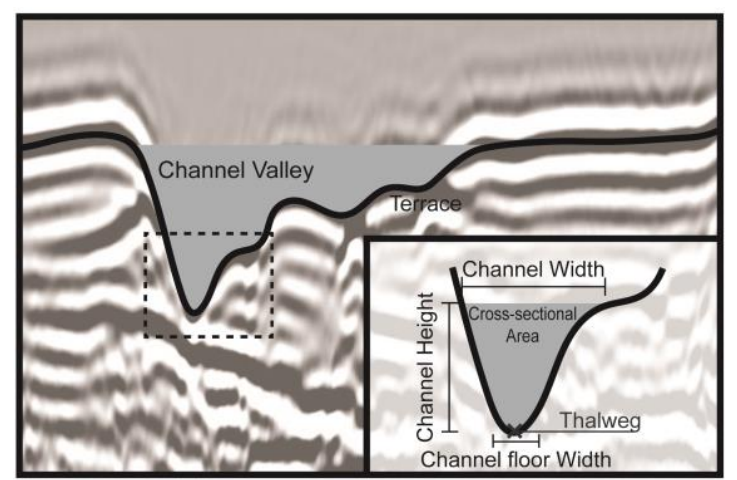

Figure 2 - Measurements taken for the channel system in this work.

\section{Current Calculation}

The cross-sectional geometry of river or submarine channels, like width, depth and slope have demonstrated to be a function of the water and sediment flux hydrodynamic behavior (BAKER, 1974; COSTA, 1983; KONSOER; ZINGER; PARKER, 2013; LEOPOLD; WOLMAN; MILLER, 1964). Konsoer et al. (2013) proposed an equation based on the analysis of 177 cross sections profiles from 23 submarine channels and 231 cross sections from rivers to estimate mean flow velocities and discharges of submarine channels. His work is based on morphometric features as volumetric sediment concentration values of turbidity currents, slope and the coefficient of friction in the modified Chezy equation. That incorporates the channel bed flow resistance and the interface between the turbidity current and the ambient fluid above. 
Channel velocity $(v)$ can be estimated as (KONSOER; ZINGER; PARKER, 2013):

$$
v^{2}=(R \times C \times g \times H) / \mathrm{R}_{\mathrm{i}}
$$

Where $R$ is given by $R=\left(\rho_{\text {sed }}-\rho_{w}\right) / \rho_{w}$ and $\rho_{\text {sed }}$ and $\rho_{w}$ are the density of sediment and water, respectively. $C$ is the sediment concentration; $g$ is the gravity (ca. 9,8 m/s); $H$ is the depth, and $R_{i}$ is the Richardson number (that can be solved according to Konsoer et al., 2013). Using the channel width $(B)$ and depth $(H)$, of the cross-section profile, and the flow velocity previously calculated. The discharge $(Q)$ of submarine turbidity systems can be solved through:

$$
Q=v \times B \times H
$$

\section{Results and Discussion}

\section{Seismic Interpretation}

Seismic facies were interpreted based on their geometry, continuity and amplitude reflections (MITCHUM; VAIL; SANGREE, 1977). Four main seismic facies were associated with the submarine channel system (Table 1).

Table 1 - Description and interpretation of seismic facies

\begin{tabular}{|c|c|}
\hline Seismic Facies & 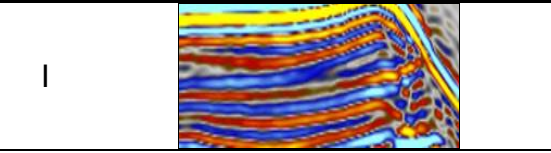 \\
\hline Description & $\begin{array}{l}\text { Parallel to subparallel reflectors with } \\
\text { lateral gull-wing shaped features; low- } \\
\text { to medium- amplitude; and continuous } \\
\text { to discontinuous seismic reflections }\end{array}$ \\
\hline Interpretation & $\begin{array}{l}\text { Channel overbank deposits } \\
\text { (Levees) }\end{array}$ \\
\hline Seismic Facies & II \\
\hline Description & $\begin{array}{l}\text { Continuous high amplitude reflectors } \\
\text { (HARs) confined by the channel or } \\
\text { paleochannel feature }\end{array}$ \\
\hline Interpretation & $\begin{array}{l}\text { Basal lags of channels or lobe } \\
\text { elements (distal) }\end{array}$ \\
\hline Seismic Facies & a \\
\hline Description & $\begin{array}{l}\text { Chaotic reflections, discontinuous and } \\
\text { variable amplitude }\end{array}$ \\
\hline Interpretation & Mass transport deposits (MTD) \\
\hline Seismic Facies & NOE \\
\hline Description & $\begin{array}{l}\text { Continuous to discontinuous, parallel, } \\
\text { variable amplitude reflectors }\end{array}$ \\
\hline Interpretation & Low energy deposits \\
\hline
\end{tabular}
observed in the channel system.

Facies I are the fine-sediments deposited by overbanking when flow height exceeds the channel bank height. Facies II correspond to the coarse-grain sediments accumulated at the channel base, result of the sediments by-pass from the continental shelf to the basin. Facies III represents the mass-transport sediment deposits (with no internal stratification) caused by slides, slumps or debris flows that overlap the deeper HARs. Facies IV are attributed to the sediment deposited in a low energy environment prior to or after the action of the turbidity current.

Seismic interpretation provided 3 distinct deposit patterns that can be linked to their geographical position in the continental slope (Figure 5). From 600 to $1100 \mathrm{~m}$, the middle slope of Campos Basin (segment 2), the submarine channels present an incised shape with lateral levees (levee-channel) and HARs in the subsurface interpreted as paleo-channels that have migrated vertically. From 1200 to $1600 \mathrm{~m}$ (segment 3), the channels pass to an unconfined system (valleys or lobes with a preferred path). That receives a lateral contribution from other system and has a well-marked subsurface paleo-channel of high amplitude that eroded sedimentary layers and mass movement deposits. And finally, seismic profiles in the distal area showed the influence of the salt diapirs at the seafloor reflecting in depressions (valleys) bordered by halokinesis, forming mini-basins with two flow paths (segment 4).

\section{Quantitative Analysis}

The channels feature is observed from a $\sim 600 \mathrm{~m}$ of water depth (w. d.) and goes until 2100 meters in the seismic profiles available. The marine turbidity system is composed of two pathways (Figure 1). The oldest one (dated after the hemipelagic sediment deposits over the channel feature) has an east-west direction and was captured by the second and main channel that runs in a southeast-northwest direction. The main channel presents characteristics of greater transport activity and erosion by incision (ALMEIDA; KOWSMANN, 2014).

Morphological changes were analyzed for the active channel, from the channel head ( $600 \mathrm{~m}$ w.d.) to the least profile with a single flow path $(\sim 1700 \mathrm{~m}$ w.d.) in segment 3. Afterwards, the paleo-current were calculated. It extends for $76 \mathrm{~km}$, within the data set, counting from the $200 \mathrm{~m}$ water depth (i.e. continental shelf break). Fourteen external geometries were observed, presenting an average depth (channel height) of 33.2 meters, an average width of 1062 meters and a height/width ratio of 39.7 meters. From the morphometric analysis, three domains were pointed out (Figure 3).

Channel Segment 1, between $5 \mathrm{~km}$ and $11 \mathrm{~km}$, shows shallow and short channels due to the influence of channel filling by hemipelagic sediments responsible for Itabapoana system feeder canyon burial (MACHADO et al., 2004). Segment 2 goes from $11 \mathrm{~km}$ to $32 \mathrm{~km}$ and corresponds to the main erosional channel, consequently, they have the deepest features and consequently the largest areas, with depths much greater than the width measurements. The last interval with internal channel features, segment 3 , presents measures closer in width and depth but with an area larger than the segment 1 due to its unconfined flow, forming larger channels. 


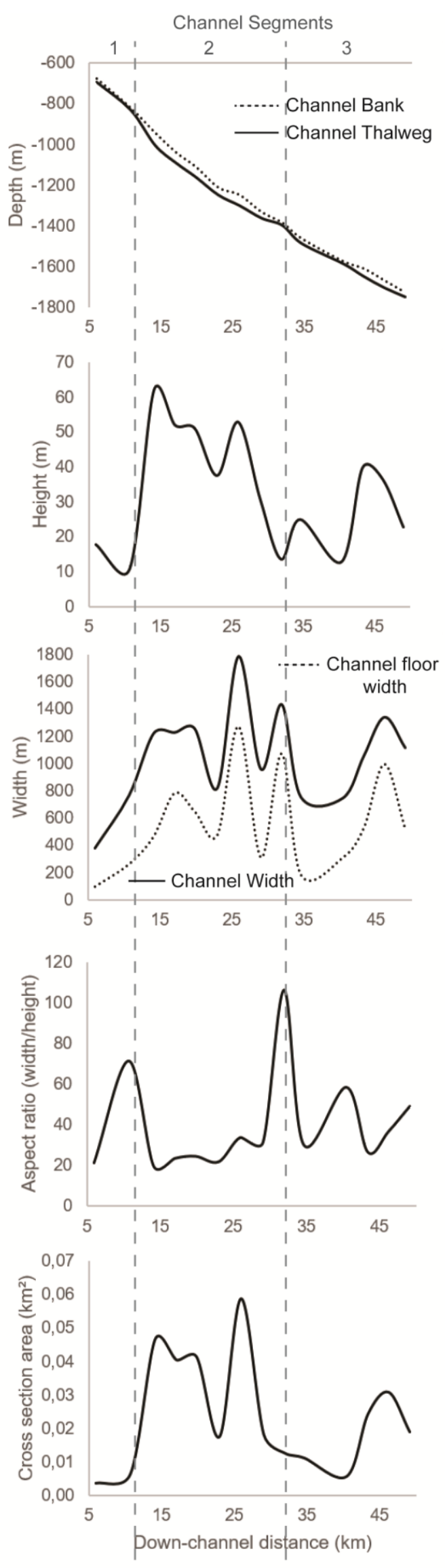

\section{Current Velocity and Discharge}

Flow discharge and current velocity for the channel system were calculated using the morphometric values and the necessary parameters as the coefficient of friction bed $\left(\mathrm{C}_{\mathrm{fb}}\right)(0.002)$, sediment density $\left(\rho_{\text {sed }}\right)\left(\right.$ of $\left.1.8 \mathrm{~g} / \mathrm{cm}^{3}\right)$, water density $\left(\rho_{w}\right) \quad\left(1 \mathrm{~g} / \mathrm{cm}^{3}\right)$, and a sediment concentration $(C)$ (of 0.002). Calculations were made for the main channel in segments 1 to 3 (Figure 5)

The average flow and discharge of the for the entire system was $1.03 \mathrm{~m} / \mathrm{s}$ and $4.74 \times 10^{4} \mathrm{~m}^{3} / \mathrm{s}$, respectively. These results show the magnitude of the submarine flows when compared to the aerial fluvial systems like the Paraíba do Sul river with $1118 \mathrm{~m} / \mathrm{s}$, pointed by Machado et al. (2014) to be responsible for feeding the Itabapoana turbidity system. Showing there is an order of magnitude in the difference between aerial and marine systems. But when compared to other channel responses in the continental slope, the values encountered are similar to the vertical aggrading channels in the Equatorial Guinea of 2.33 to $2.11 \mathrm{~m} / \mathrm{s}$ and 1.1 to $9.1 \times 10^{4} \mathrm{~m}^{3} / \mathrm{s}$ (LI; GONG; STEEL, 2018) and to the mean values observed by Konsoer et al. (2013) for submarine channels, that is, 1.02 to $2.21 \mathrm{~m} / \mathrm{s}$ and between 4 and $8 \times 10^{4} \mathrm{~m}^{3} / \mathrm{s}$.

Analyzing the current flow along the channel the same three intervals are displayed in the results (Figure 4). The filled channel head presents an inaccurate value for the probable paleo current that acted in the Itabapoana channel system. However, in segment 2, ruled by the active channels with deeper and sharper features, the velocity and discharge flows have the highest values representing the greater activity in the continental slope.

The decrease of the speed and the abrupt drop of the discharge from segment 2 to segment 3 are marked by the transition of the confined to the unconfined channel system, also defined by the change in the seafloor slope.

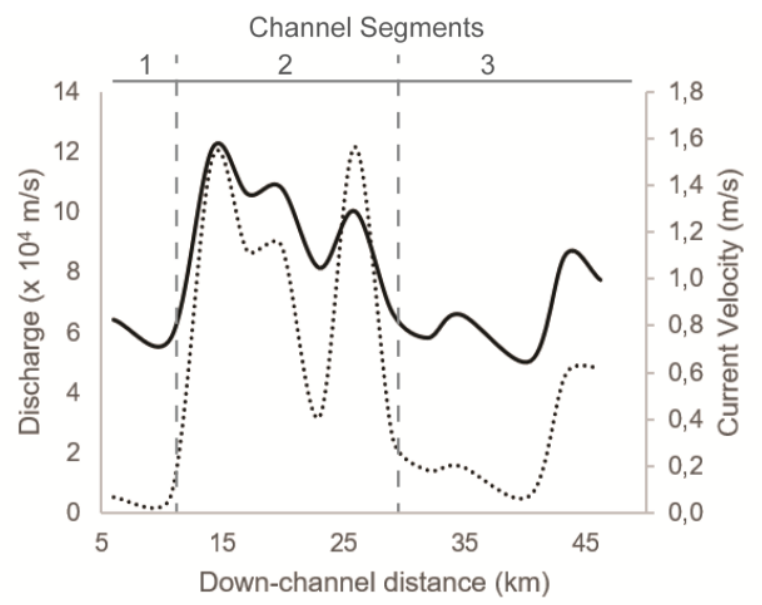

Figure 4 - Flow velocity and discharge through channel system based in the channel morphology.

Figure 3 - Quantitative analyses of the channel and the three main intervals. 


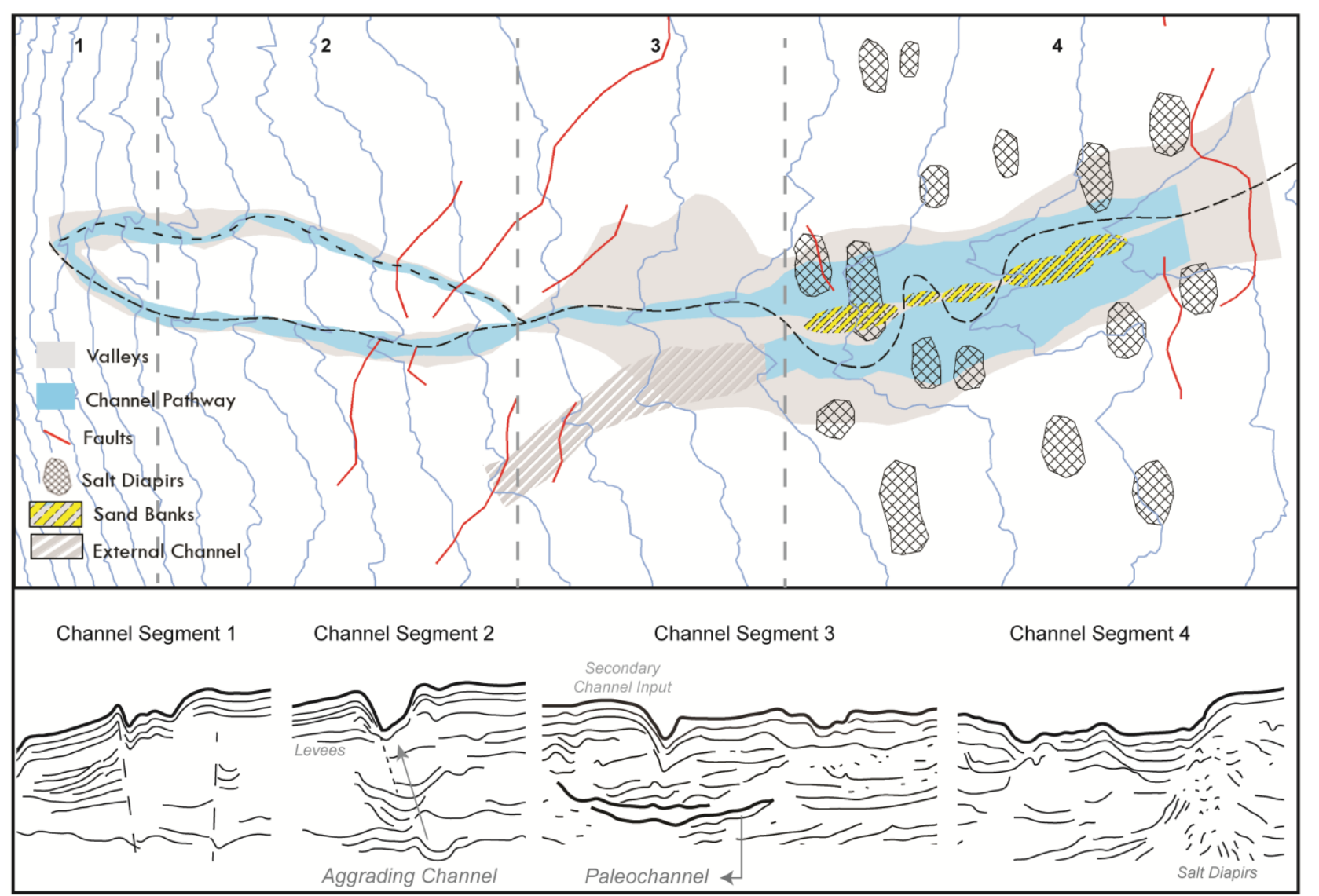

Figure 5 - Channel interpretation and division based on the seismic profiles, geometry analysis, and current calculation.

\section{Conclusions}

Channel spatialization combined with the seismic stratigraphic and morphometric analyses demonstrated that the geomorphological characteristics of the channels are related to the different deposition events and, consequently, with different flow intensities in the basin. Where the domains for the seismic interpretation and the intervals for the geomorphological analyses coincide in their position along the channel.

Fault zones and halokinesis are shown to be important factors for control of the submarine channels. Fault zones along with the continental slope change to the abyssal rise marked the transition of a confined deep channels system to an unconfined and shallow system with large paleo-channel in the subsurface.

Seismic evidence suggests that coarse-sediments or turbidity sands were deposited in the distal system prior to the halokineses events. And only after the salt rises the path flow changed and eroded these deposits leaving sediment mounds between channels depressions. Thus, the salt diapirs on the edge of the valley controlled the main path of the flow, evidenced by the change in the channel thalweg in the distal area.

The paleocurrent results found are correlated to the changes in the seafloor declivity. Thus, a higher (5.54 x
$10^{4} \mathrm{~m}^{3} / \mathrm{s}$ ) value is presented in the continental middle slope and an abrupt decrease $\left(2.93 \times 10^{4} \mathrm{~m}^{3} / \mathrm{s}\right)$ in flow discharge delineates the passage from the lower slope to the São Paulo Plateau.

This study showed that the use of available data of the Oil and Gas Industry are very efficient to investigate Quaternary processes and the seabed geomorphology. And that the submarine channels formation is the result of successive responses between the action of the turbidity currents and the tectonic environment of the basin.

\section{Acknowledgments}

Thanks to Thaise Ricardo, the Coastal Oceanography Laboratory (LOC) at Federal University of Santa Catarina (UFSC), National Agency of Petroleum, Natural Gas and Biofuel (ANP) and Petrobras for its support in the development of the cooperation between Petrobras, ANP and UFSC.

\section{References}

ABREU, J. G. N.; CALLIARI, L. J. Paleocanais na Plataforma Continental interna do Rio Grande do Sul: evidências de uma drenagem fluvial pretérita. Revista Brasileira de Geofisica, v. 23, n. 2, p. 123-132, 2005.

ALMEIDA, A. G.; KOWSMANN, R. O. Geomorfologia Do Talude Continental E Do Platô De São Paulo. In: KOWSMANN, R. O. (Ed.). . Geologia e Geomorfologia. 
1. ed. Rio de Janeiro: Elsevier Editora Ltda., 2014. p. 3366.

BAKER, V. R. Paleohydraulic Interpretation of Quaternary Colorado Alluvium. Quaternary Research, v. 12, n. 4, p. 94-112, 1974.

BRUSH, E. R. et al. The Rio Doce canyon system in the northern Espirito Santo Basin, offshore Brazil: a model for interpreting ancient deep-water sand transportation fairways. Annual Meeting Expanded Abstracts American Association of Petroleum Geologists, v. 13, p. 19, 2004.

CASTRO, R. D. DE; PICOLINI, J. P. Principais Aspectos $\mathrm{Da}$ Geologia Regional Da Bacia De Campos. In: KOWSMANN, R. O. (Ed.). . Geologia e Geomorfologia. 1. ed. Rio de Janeiro: Elsevier Editora Ltda., 2014. p. 112.

CHOPRA, S.; MARFURT, K. J. Seismic attributes - A historical perspective. Geophysics, v. 70, n. 5, p. 3SO28SO, 2005.

COSTA, J. E. Paleohydraulic reconstruction of flash- flood peaks from boulder deposits in the Colorado Front Range. Geological Society of America Bulletin, v. 94, n. 8, p. 986-1004, 1983.

GIBLING, M. R. Width and Thickness of Fluvial Channel Bodies and Valley Fills in the Geological Record: A Literature Compilation and Classification. Journal of Sedimentary Research, v. 76, n. 5, p. 731-770, 2006.

GUARDADO, L. R.; GAMBOA, L. A. P.; LUCCHESI, C. F. Petroleum Geology of the Campos Basin, Brazil, a Model for a producing atlantic type basin. Divergent/Passive Margins Basins, v. 48, p. 3-36, 1989.

JANOCKO, M. et al. The diversity of deep-water sinuous channel belts and slope valley-fill complexes. Marine and Petroleum Geology, v. 41, n. 1, p. 7-34, 2013.

KONSOER, K.; ZINGER, J.; PARKER, G. Bankfull hydraulic geometry of submarine channels created by turbidity currents: Relations between bankfull channel characteristics and formative flow discharge. v. 118, p. 216-228, 2013.

KOSON, S.; CHENRAI, P.; CHOOWONG, M. Seismic Attributes and Their Applications in Seismic Geomorphology. Bulletin of Earth Sciences of Thailand, v. 6, n. 1, p. 1-9, 2014.

LEOPOLD, L. B.; WOLMAN, M. G.; MILLER, J. P. Fluvial processes in geomorphology. Dover Publications, 1964. v. 3

LI, L.; GONG, C.; STEEL, R. J. Bankfull discharge as a key control on submarine channel morphology and architecture: Case study from the Rio Muni Basin, West Africa. Marine Geology, v. 401, n. April, p. 66-80, 2018.

LINK, M. H. et al. Seismic Facies and Sedimentary Processes of Submarine Fans and Turbidite Systems. New York: Springer Science Business Media, 1991.

MCHARGUE, T. et al. Architecture of turbidite channel systems on the continental slope: Patterns and predictions. Marine and Petroleum Geology, v. 28, n. 3, p. 728-743, 2011.

MEIBURG, E.; KNELLER, B. Turbidity Currents and Their Deposits Turbidity Currents and Their Deposits. Annual Review of Fluid Mechanics, v. 1, n. January, p. 1-50, 2009.

MIDDLETON, G. V; HAMPTON, M. A. Subaqueous sediment transport and deposition by sediment gravity flows. In: STANLEY, D. J.; SWIF, D. J. P. (Eds.). . Marine sediment transport and environmental management. [s.l: s.n.]. p. 197-218.

MITCHUM, R. M.; VAIL, P. R.; SANGREE, J. B. Seismic stratigraphy and global changes of sea level interpretation patterns sequences.pdf. American Association Geological Bulletin, v. 26, p. 53-62, 1977.

MORAES, M. A. S.; BLASKOVSKI, P. R.; PARAIZO, P. L. B. Arquitetura de reservatórios de águas profundas. Boletim de Geociencias da Petrobras, v. 14, n. 1, p. 725, 2005.

MOREIRA, J. L. P.; CARMINATTI, M. Sistemas deposicionais de talude e de bacia no Eoceno da Bacia de Santos. Boletim de Geociencias da Petrobras, v. 12 , n. 1, p. 73-87, 2003.

NORDFJORD, S. et al. Seismic geomorphology of buried channel systems on the New Jersey outer shelf: Assessing past environmental conditions. Marine Geology, v. 214, n. 4, p. 339-364, 2005.

OSORIO, J. S. L. 3D Geological Modeling of the Oligocene-miocene turbidite system in the eastern Marlim Oilfield, Campos Basin, Brazil. [s.l.] Universidade Estadual de Campinas, 2017.

POSAMENTIER, H. W.; KOLLA, V. SEISMIC GEOMORPHOLOGY AND STRATIGRAPHY OF DEPOSITIONAL ELEMENTS IN DEEP-WATER SETTINGS. Journal of Sedimentary Research, v. 73, n. 3, p. 367-388, 2003.

POSAMENTIER, H. W.; WALKER, R. G. Facies Models Revisited. Society for Sedimentary Geology, 2006.

QIN, Y. et al. Quantitative seismic geomorphology of a submarine channel system in SE Brazil (Espírito Santo Basin): Scale comparison with other submarine channel systems. Marine and Petroleum Geology, v. 78, p. 455473, 2016.

RIZZO, J. G. et al. Movimento de massas e fluxos gravitacionais na Bacia de Campos: ocorrência e a utilização das variações do nível do mar como fator de predição. Anais do $3^{\circ}$ Congresso Brasileiro de Geologia, v. 3, n. 2, p. 297-298, 1994.

SHEPARD, F. P. Submarine canyons. Earth-Science Reviews, v. 8, p. 1-12, 1972.

SHEPARD, F. P. Submarine Canyons: Multiple Causes and Long-Time Persistence. The American Association of Petroleum Geologists, p. 1062-1077, 1981.

WESCHENFELDER, J. et al. Quaternary incised valleys in southern Brazil coastal zone. Journal of South American Earth Sciences, v. 55, p. 83-93, 2014. 